METALLURGY AND MATERIALS TECHNOLOGY

DOI 10.5862/JEST.249.8

УДК 669.1.017:669.018.44:669.018.28

S.Yu. Kondrat'ev, G.P. Anastasiadi, A.V. Ptashnik

\title{
MICROSTRUCTURAL EVOLUTION OF HEAT- RESISTANT HP ALLOYS UNDER LONG-TIME OPERATION AT HIGH TEMPERATURES
}

\author{
С.Ю. Кондратьев, Г.П. Анастасиади, А.В. Пташник
}

\begin{abstract}
ЭВОЛЮЦИЯ МИКРОСТРУКТУРЫ ЖАРОПРОЧНЫХ НР СПЛАВОВ ПРИ ДЛИТЕЛЬНОЙ ВЫСОКОТЕМПЕРАТУРНОЙ ЭКСПЛУАТАЦИИ
\end{abstract}

\begin{abstract}
The structural instability of Fe-Cr-Ni-based superalloys and the mechanism of softening at operating temperatures were studied. We investigated the continuous changes in the structure and kinetics of dissolution of initial phases with formation and dissolution of intermediate phases of the cast superalloy $0,45 \mathrm{C}-26 \mathrm{Cr}-33 \mathrm{Ni}-2 \mathrm{Si}-2 \mathrm{Nb}$ under long-time operation at high temperature. The character and the sequence of phase transformations in $\mathrm{Fe}-\mathrm{Cr}-\mathrm{Ni}$-based alloys at a temperature of 0,85-0,90 of their solidus, also under external loading, were found out. The structural instability of Fe-Cr-Ni-based superalloys and the mechanism of softening at operating temperatures were studied.
\end{abstract}

MICROSTRUCTURE; PHASE COMPOSITION; CAST MODIFIED 25CR-35NI HEAT-RESISTANT ALLOYS; DIFFUSION IN ALLOYS; STRUCTURAL STABILITY; KINETICS OF PHASE TRANSFORMATIONS.

\begin{abstract}
Изучены структурная нестабильность и механизм разупрочнения при температурах эксплуатации жаропрочных сплавов на основе системы $\mathrm{Fe}-\mathrm{Cr}-\mathrm{Ni}$. Исследованы непрерывные изменения структуры и кинетика растворения первичных фаз с образованием и последующим растворением промежуточных фаз в литом жаропрочном сплаве $0,45 \mathrm{C}-26 \mathrm{Cr}-33 \mathrm{Ni}-2 \mathrm{Si}-2 \mathrm{Nb}$ при длительной высокотемпературной эксплуатации. Выявлены характер и природа фазовых превращений в сплавах на основе системы Fe-Cr-Ni при температурах 0,85-0,90 от температуры солидус, а также под действием внешней нагрузки. Изучены структурная нестабильность и механизм разупрочнения жаропрочных сплавов на основе системы Fe-Cr-Ni при температурах эксплуатации. МИКРОСТРУКТУРА; ФАЗОВЫЙ СОСТАВ; ЛИТЫЕ МОДИФИЦИРОВАННЫЕ ЖАРОПРОЧНЫЕ СПЛАВЫ 25CR-35NI; ДИФФУЗИЯ В СПЛАВАХ; СТРУКТУРНАЯ СТАБИЛЬНОСТЬ; КИНЕТИКА ФАЗОВЫХ ПРЕВРАЩЕНИЙ.
\end{abstract}

\section{Introduction}

The iron-nickel and nickel-based alloys are used for operation in dynamic conditions with load up to 100 thousand hours at temperatures to $700-900^{\circ} \mathrm{C}$, i.e. $T_{\text {op }}=(0,60-0,80) \mathrm{sol}\left(T_{\text {op }}\right.$ and $T_{\text {sol }}-$ operating temperature and alloy solidus). They have an unstable structure and are prone to a continuous change during the operation [1-5]. This process can't be stabilized by thermal pre-treatment, including heating up to $1050-1200{ }^{\circ} \mathrm{C}$ followed by cooling and prolonged aging. During continuous operation alloys embrittle due to the evolution in the structure of the intermediate phases $\sigma, \chi, \mu, G, Z, \gamma$. Intermediate phases have different chemical composition, significantly different from the average composition of the alloy and the composition of the matrix $\gamma$-phase [6-14].

The primarily alloys of iron-chromium-nickelbased are used for manufacturing of equipment used in the processing of oil and gas, operating at temperatures of $900-1000^{\circ} \mathrm{C}$ with a brief overheating to $1100-1200^{\circ} \mathrm{C}$. They contain a high amount of carbon - to $0,30-0,70 \%$ (wt.) and are stabilized with $\mathrm{Nb}$, 
Ti, Mo, W, N and other elements. Alloys operating temperature under these conditions reaches $T_{\text {op }}=(0,80-0,85) T_{\text {sol }}$, which is an unique example of the use of heat-resistant material. Large blanks with wall thickness up to $50 \mathrm{~mm}$ are made by stationary and centrifugal casting. Structure of $\mathrm{Cr} 25 \mathrm{Ni35}-$ alloys, containing (\%,wt.) $0,4-0,5 \mathrm{C}, 2 \mathrm{Si}, 2 \mathrm{Nb}$, has an explicit metallographically inhomogeneous dendritic structure with the length of the first-order branches up to $3000 \mu \mathrm{m}$, a width of $200 \mu \mathrm{m}$, the length second-order branches up to $300 \mu \mathrm{m}$ and width up to $100 \mu \mathrm{m}$. The original cast structure consists of three main phases: matrix solid solution ( $\gamma$-phase) $(75-$ $80 \%$, vol. $)$, eutectic consisting of $\gamma$-phase $(\sim 16 \%)$ and chromium carbides $(\sim 4,0 \%)$, matrix carbide of niobium $(\sim 2 \%)$. Such structure are formed because of a low solubility of carbon in $\gamma$-phase $(<0,1 \%)$ and segregation of chromium (up to $35 \%$ ) with a formation of eutectic liquid, which should comprise (at $80 \%$, vol. of $\gamma$-phase) the component balance of $2 \% \mathrm{C}$ and up to $35 \% \mathrm{Cr}$. The mechanism of formation of niobium carbide is less clear. Perhaps the key factor is the low solubility of $\mathrm{Nb}$ in a $\gamma$-phase $(<0,5 \%$ in comparison with its concentration in the composition of the alloy $-2 \%$ ). The structure of such alloys, formed during crystallization, is relatively stable because to change the alloy structure a substantial atoms redistribution of metal elements of basis ( $\mathrm{Fe}, \mathrm{Cr}, \mathrm{Ni}$ ) is needed. However, at a concentration of them of $25-40 \%$ at the temperature of operation, when the diffusion coefficient is $\mathrm{D}<10^{-10} \mathrm{~cm}^{2} / \mathrm{s}$ and the mean free path of atoms per 1 hour $l=(\mathrm{D} \tau)^{0,5}<6 \mu \mathrm{m}$, it is very difficult. This is a major factor in determining a preferred use of cast alloys at temperatures up to $0,8 T_{\text {sol. }}$.

However, the problems of structural instability in these alloys, nevertheless, appear to a large extent due to: firstly - cast condition characterized by a large initial structural and chemical heterogeneity, and the secondly - the impact of higher operating temperatures and significantly longer duration of operation, reaching 140 thousand hours. Price P and Grant N were the first who experimentally constructed phase diagram of the $\mathrm{Fe}-\mathrm{Cr}$-Ni-system for a temperature of $1300^{\circ} \mathrm{C}$ [Price P and Grant N. Trans AIME 1959; 215:635-37]. Apparently, it remains the only one because to reach equilibrium at lower temperatures in this system of components long holding are required - more than 100 thousand hours.

Due to the availability of strong carbide and nitride-forming elements $-\mathrm{Cr}$, $\mathrm{Ti}, \mathrm{Nb}$, and the ele- ments forming intermediate intermetallic phases with bases elements (iron, nickel and chromium) - $\mathrm{Si}$ and $\mathrm{Nb}$ in alloys of this type take place a continuous transformation of structure during high temperature holding, especially under the influence of operating stress [1-6]. Significant operating problems of parts made of alloys of this type with multiphase structure are: individual features of melting; the presence of uncontrolled impurities; blanks production technology, including foundries, plastic deformation, welding and other operations. Essentially, each batch of blanks made out of such alloys is unique with individual behavior during processing and operation. Consequently, there is an uncertainty in the comparison on the results of numerous studies of $\mathrm{Fe}-\mathrm{Cr}-\mathrm{Ni}$-alloys, received using electron microprobe analysis, scanning electron microscopy and other techniques, published mainly in 2000s. A detailed description of alloy compositions, production technology of blanks, features of heat treatment and operation, etc. is needed for the comparative analysis of continuous structural transformations observed in them at high holding. This makes it difficult to analyze and forecast the performance of alloys at extreme temperatures and duration of usage.

Thus, the study of the structural stability of Fe$\mathrm{Cr}-\mathrm{Ni}$-based superalloys and detection of the mechanism of softening at operating temperatures is an urgent challenge, the solution of which will help to find the way to extend the life of high temperature constructions produced out of them.

The purpose of this study is to investigate the stability of the structure and phase composition of the cast alloy based on the basic composition $25 \mathrm{Cr}-$ $35 \mathrm{Ni}$ during prolonged high temperature holding.

\section{Experimental procedures}

Chemical composition of the investigated alloy comprises (\%,wt.): $0,45 \mathrm{C}, 25 \mathrm{Cr}, 33 \mathrm{Ni}, 2 \mathrm{Si}, 2 \mathrm{Nb}$, as well as additives $\mathrm{W}, \mathrm{Mo}, \mathrm{Ti}, \mathrm{Al}-$ up to $1 \%$ of each element and $\mathrm{N}-$ up to $0,2 \%$. Melting of the alloy was performed in an induction furnace with a capacity of $500 \mathrm{~kg}$, castings were produced in a sand mold. Then, structure stabilization heating up to $1200{ }^{\circ} \mathrm{C}$ with cooling in a furnace or in water was carried out. The research on microstructure of the alloy was performed on the optical metallographic microscope Carl Zeiss Axiovert 40 at magnifications $\times 50 \ldots 1000$ with the use of the automatic quantitative image analysis program according to ASTM E 1245-03. Microprobe analysis of the distribution of chemical 
elements in the matrix and composition of the phases was carried out on the equipment Tescan VEGA $5136 \mathrm{LM}$ with a precise determination of the concentration (\%, relative.): for $\mathrm{Fe}, \mathrm{Ni}, \mathrm{Cr}, \mathrm{Si}, \mathrm{Nb}, \mathrm{Mo}, \mathrm{W}$, $\mathrm{Ti}-3 \%$ for $\mathrm{C}, \mathrm{N}-20 \%$. To identify the structure of the alloy there was used electrolytic etching with oxalic acid $10 \%$. Production and preparation of thin sections were performed on the equipment «Buehler» according to ASTM E 3-95. Alloy structure was investigated using scanning electron microscope Quanta 200 3D FEG.

\section{Results}

The research has shown that the structure of alloys $\mathrm{C}-25 \mathrm{Cr}-35 \mathrm{Ni}-\mathrm{Si}-\mathrm{Nb}$ in cast condition consists of matrix $\gamma$ - solid substitutional solution and carbides (fig. 1).

Solid solution has a pronounced dendritic structure with thin intercrystalline boundaries. According to statistics of microprobe analysis it contains (\%,wt.): $38 \mathrm{Fe}, 35 \mathrm{Ni}, 23 \mathrm{Cr}, 2 \mathrm{Si},<1 \%$ (each) - Nb, W, Mo. It was found that after high temperature exposure the homogeneity of the matrix increases. Thus, already after 2 hours of exposure at $1150{ }^{\circ} \mathrm{C}$ the difference in content of $\mathrm{Fe}, \mathrm{Cr}, \mathrm{Mn}$ in different parts of the solid solution is practically absent, and the difference in the content of Si decreases from $0,4-0,9$ to $0,1-0,3 \%$. The phase $\gamma$ remains stable in chemical composition and crystal structure in the temperature range of $T_{\mathrm{op}}=(0,80-0,85) T_{\text {sol }}$ at longtime holding under stress.

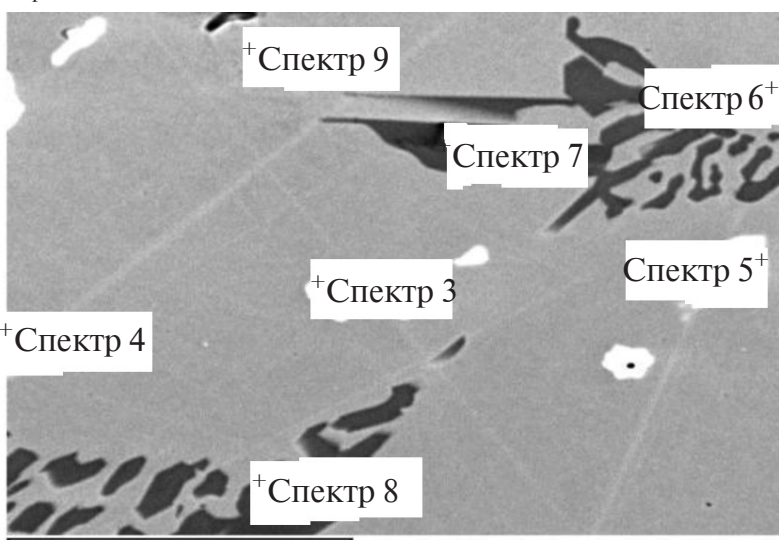

Fig. 1. Structure of alloy in cast state: matrix solid solution $-\gamma$-phase (base); carbides $\mathrm{Me}_{7} \mathrm{C}_{3}$ in eutectic

(spectrum 7,8) and $\mathrm{NbC}$ (spectrum 5, 6); carbonitrides TiN (spectrum 3, 4, 9)

Initial carbide phases consist of a eutectic carbide $\mathrm{M}_{7} \mathrm{C}_{3}$ on chromium base and niobium carbide, which has titanium carbonitride inside (fig. 2, 3). In carbide $\mathrm{M}_{7} \mathrm{C}_{3}$ are being dissolved (\%,wt.) up to $9 \mathrm{Fe}$ and 2
- Ni, W, Mo (each) and in $\mathrm{NbC}$ - up to $1 \mathrm{Fe}, \mathrm{Cr}$, $\mathrm{Ni}, \mathrm{Ti}$ (each). During the electron microscope research of the alloy structure in the initial cast condition no fragmentation of chromium and niobium carbides was detected.

a)

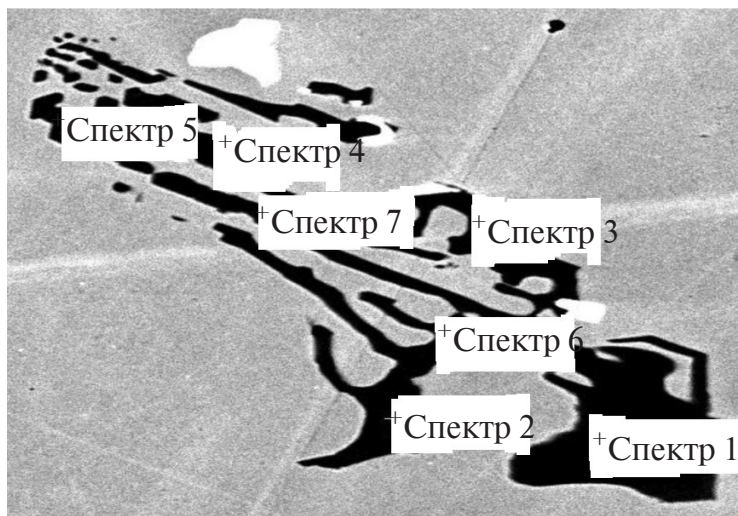

$30 \mathrm{Mkm}$

Электронное изображение 1

b)

\begin{tabular}{|c|c|c|c|c|c|c|}
\hline \multirow{2}{*}{ Spectrum } & \multicolumn{6}{|c|}{ Content of elements, \% (wt.) } \\
\hline & C & $\mathrm{Cr}$ & $\mathrm{Fe}$ & $\mathrm{Ni}$ & Mo & W \\
\hline 1 & 9.27 & 79.36 & 7.65 & 1.47 & 0.73 & 1.52 \\
\hline 2 & 9.36 & 79. & | 7.38 & 1.53 & & 1.41 \\
\hline 3 & 8.87 & 78. & | 8.84 & 1.70 & 0.5 & 1.30 \\
\hline 4 & 9. & 78.69 & | 8.36 & 1.88 & & 1.29 \\
\hline 5 & & & & 1.97 & 0.67 & 1.53 \\
\hline 6 & & & 9. & 2.06 & 0. & 1.44 \\
\hline 7 & 8.94 & 78.29 & 9.13 & $\mid 1.65$ & 0.61 & 1.38 \\
\hline
\end{tabular}

Fig. 2. Structure of cast alloy $(a)$ and the composition of the niobium carbide $(b)$

a)

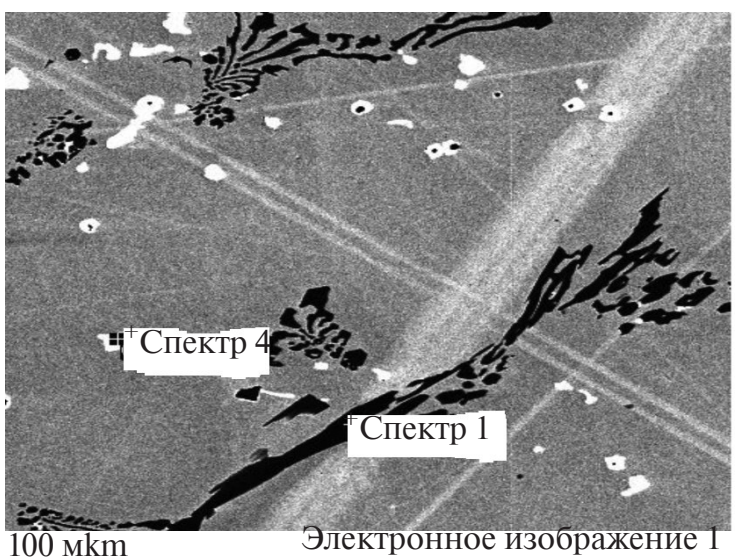

b)

\begin{tabular}{|c|c|c|c|c|c|c|}
\hline \multirow{2}{*}{ Spectrum } & \multicolumn{5}{|c|}{ Content of elements, \% (wt.) } \\
\cline { 2 - 7 } & $\mathrm{C}$ & $\mathrm{Ti}$ & $\mathrm{Cr}$ & $\mathrm{Fe}$ & $\mathrm{Ni}$ & $\mathrm{Nb}$ \\
\hline 4 & 11.40 & 0.86 & 1.09 & 0.68 & 0.67 & 85.30 \\
\hline
\end{tabular}

Fig. 3. Structure of cast alloy $(a)$ and the composition of the niobium carbide $(b)$ 


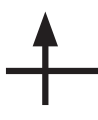

After holding at $1150{ }^{\circ} \mathrm{C}$ for 2 hours chromium carbide $\mathrm{M}_{7} \mathrm{C}_{3}$ with hexagonal lattice is transforming into $\mathrm{M}_{23} \mathrm{C}_{6}$ with FCC lattice (fig. 4, 5 and table 1).

The excess carbon is used for the formation of intermediate dispersed carbides, formed in the matrix outside the zone of $5 \mu \mathrm{m}$ from the boundaries of eutectic chromium carbides (fig. 5-6, 7a). After hightemperature holding fragmentation of carbides is detected (fig. 4, 5). Analysis of the shape of carbides in the alloy structure allows assuming that chromium carbide with a smooth convex surface grew in the liquid melt and niobium carbide with drawn surface portions - in the solid phase.

Table 1

The average chemical composition of eutectic carbides in the structure of alloy in cast state and after holding at $1150{ }^{\circ} \mathrm{C}$ of varying duration

\begin{tabular}{|c|c|c|c|c|c|c|c|c|}
\hline \multirow{2}{*}{ № } & \multirow{2}{*}{ State of the alloy } & \multirow{2}{*}{ Region of the carbide } & \multicolumn{5}{|c|}{ Content of elements, \% (wt.) } \\
\cline { 4 - 8 } & & & $\mathrm{C}$ & $\mathrm{Cr}$ & $\mathrm{Fe}$ & $\mathrm{Ni}$ & $\mathrm{Mo}$ & $\mathrm{W}$ \\
\hline 1 & $\mathrm{as}-\mathrm{Cast}$ & - & 9,10 & 78,76 & 8,51 & 1,55 & 0,66 & 1,42 \\
2 & $1150^{\circ} \mathrm{C}, 2 \mathrm{~h}$ & Dark & 10,31 & 71,14 & 11,82 & 4,40 & 0,78 & 1,55 \\
& & Light & 9,23 & 69,61 & 12,26 & 4,62 & 1,33 & 2,95 \\
3 & $1150^{\circ} \mathrm{C}, 50 \mathrm{~h}$ & - & 5,61 & 72,84 & 12,76 & 4,38 & 1,24 & 3,17 \\
4 & $1150^{\circ} \mathrm{C}, 100 \mathrm{~h}$ & - & 5,42 & 73,16 & 12,63 & 4,37 & 1,16 & 3,26 \\
\hline
\end{tabular}

a)

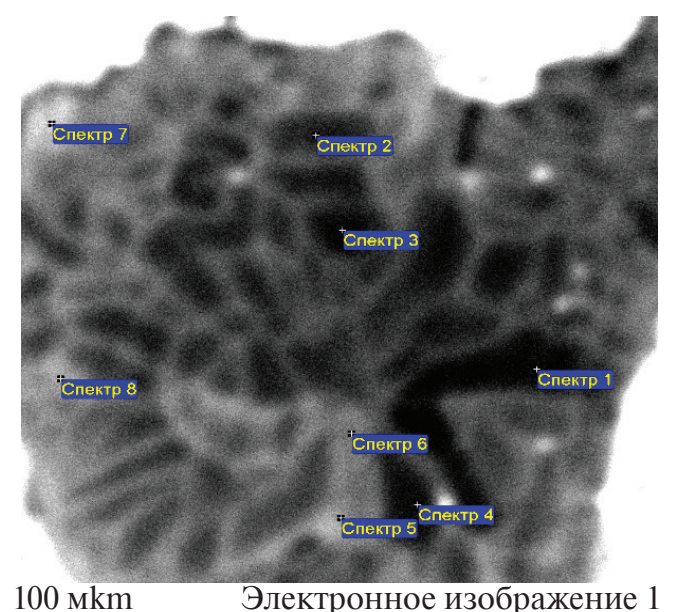

$100 \mathrm{mkm} \quad$ Электронное изображение 1 b)

\begin{tabular}{|c|c|c|c|c|c|c|}
\hline \multirow{2}{*}{ Spectrum } & \multicolumn{5}{|c|}{ Content of elements, \% (wt.) } \\
\cline { 2 - 6 } & $\mathrm{C}$ & $\mathrm{Cr}$ & $\mathrm{Fe}$ & $\mathrm{Ni}$ & $\mathrm{Mo}$ & $\mathrm{W}$ \\
\hline $\mathbf{1}$ & $\mathbf{1 0 . 0 6}$ & $\mathbf{7 1 . 6 5}$ & $\mathbf{1 1 . 8 2}$ & $\mathbf{4 . 2 1}$ & $\mathbf{0 . 7 8}$ & $\mathbf{1 . 4 8}$ \\
$\mathbf{2}$ & $\mathbf{9 . 8 5}$ & $\mathbf{7 1 . 6 2}$ & $\mathbf{1 2 . 3 6}$ & $\mathbf{3 . 9 7}$ & $\mathbf{0 . 6 8}$ & $\mathbf{1 . 5 2}$ \\
$\mathbf{3}$ & $\mathbf{9 . 2 3}$ & $\mathbf{7 1 . 7 5}$ & $\mathbf{1 1 . 8 9}$ & $\mathbf{4 . 7 6}$ & $\mathbf{0 . 8 4}$ & $\mathbf{1 . 5 3}$ \\
$\mathbf{4}$ & $\mathbf{1 0 . 2 9}$ & $\mathbf{7 0 . 5 8}$ & $\mathbf{1 2 . 2 4}$ & $\mathbf{4 . 5 6}$ & $\mathbf{0 . 7 6}$ & $\mathbf{1 . 5 7}$ \\
\hline $\mathbf{5}$ & 9.28 & 68.83 & 12.99 & 4.75 & 1.28 & 2.87 \\
$\mathbf{6}$ & 9.61 & 69.56 & $12.10 \mid$ & 4.43 & $1.36 \mid 2.94$ \\
7 & 8.80 & 70.27 & 11.75 & 4.77 & $1.25 \mid 3.16$ \\
$\mathbf{8}$ & 9.26 & 69.89 & 12.27 & 4.34 & 1.48 & $\mathbf{2 . 7 6}$ \\
\hline
\end{tabular}

Fig. 4. Structure $(a)$ and chemical composition of different parts $(b)$ of the eutectic carbide $\mathrm{Me}_{\mathrm{x}} \mathrm{C}_{\mathrm{y}}$ in the alloy after holding at $1150{ }^{\circ} \mathrm{C}$ for $2 \mathrm{~h}$
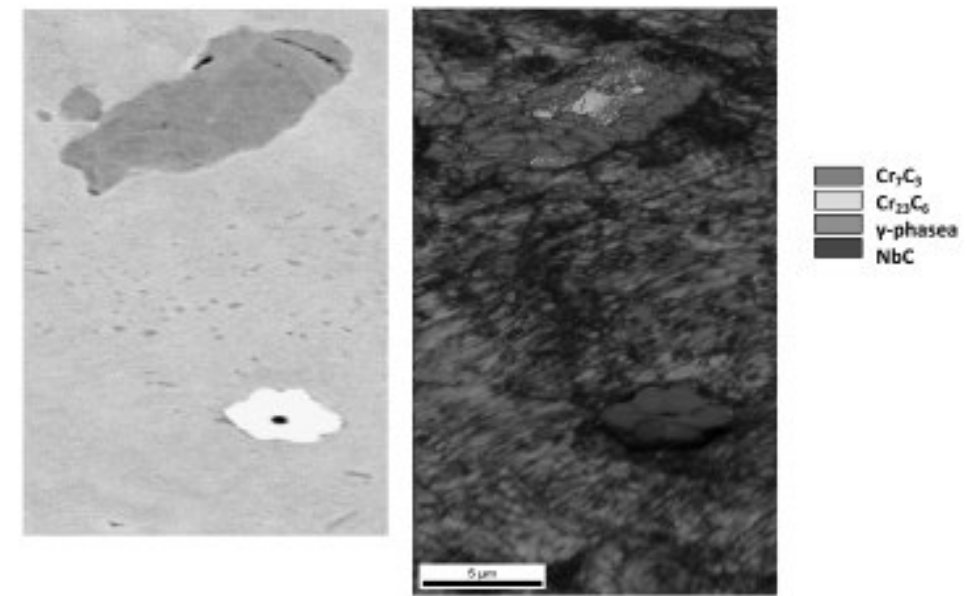

Fig. 5. Structure of alloy after holding at $1150{ }^{\circ} \mathrm{C}$ for 50 hours in back-scattered electron $(a)$ and phase distribution map, superimposed on quality diffraction patterns map $(b)$ 
Intermediate intermetallic phases with different and changing composition types of $\sigma$-phase and $\gamma^{\prime}$ phase with niobium, silicon or niobium and silicon simultaneously are being formed at the boundary of the matrix phase with eutectic chromium carbide and at the boundary of the matrix with niobium carbide, as well as isolated in the matrix at a high temperature holding (fig. 7,b). Increasing of the duration of high temperature holding of the alloy leads to the partial dissolution of primary carbides both chromium and niobium based. This is evidenced by the formation of jagged (relief) boundaries between carbides and matrix (fig. 8,a). Also possible is «sprouting» of individual niobium carbides (fig. 8, $b$, spectrum 2) through branches of eutectic chromium carbides, this process goes by stages - with formation of the intermediate $\gamma^{\prime}$-phase (fig. 8, $b$, spectrum 3) containing up to $16 \%$ (wt.) of niobium. a)
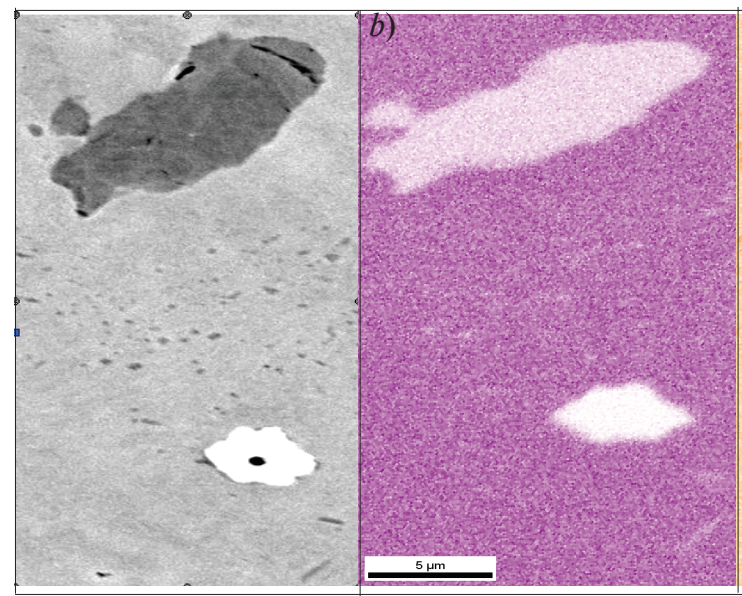

$\mathrm{Fe}$

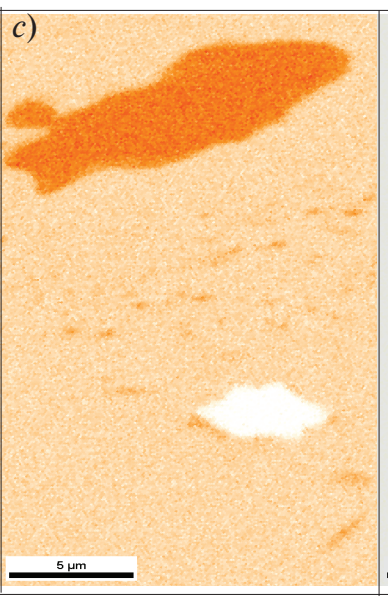

$\mathrm{Cr}$

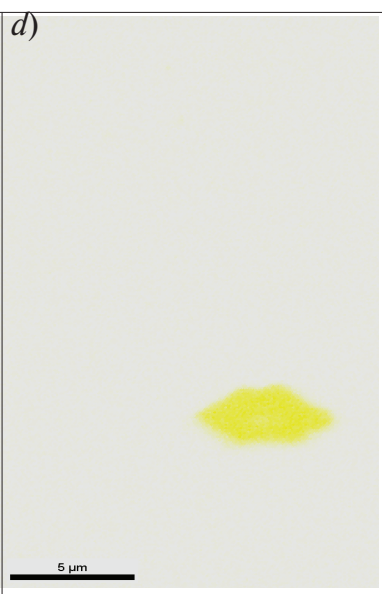

$\mathrm{Nb}$

Fig. 6. Structure of alloy in back-scattered electrons $(a)$ and the distribution map of the chemical elements (iron, chromium and niobium) after holding at $1150^{\circ} \mathrm{C}$ for $100 \mathrm{~h}$

a)
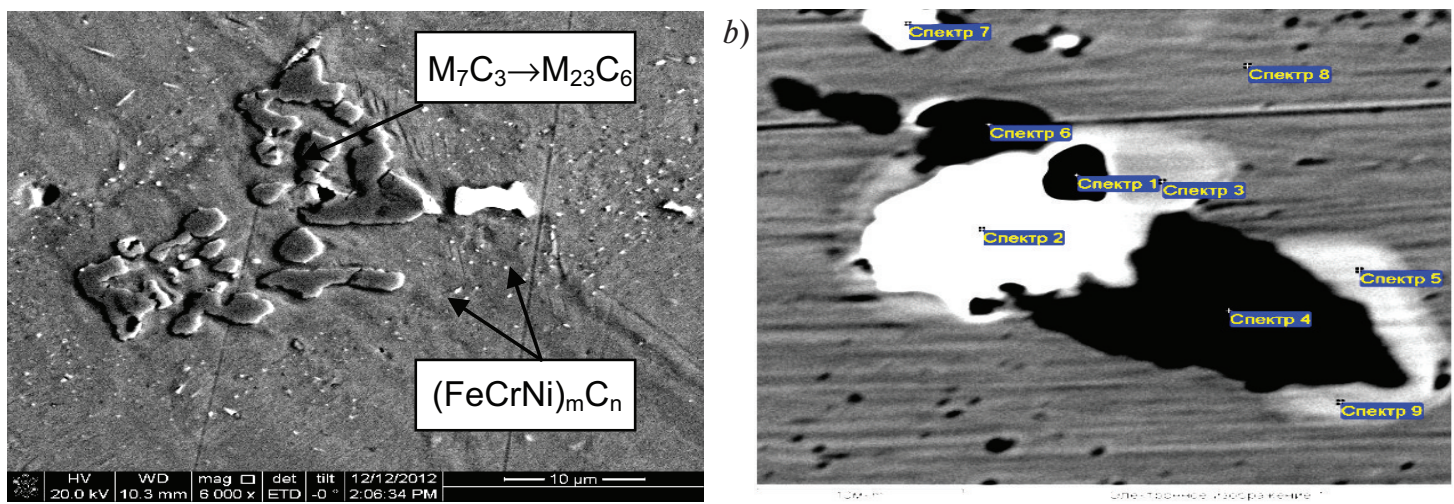

Fig. 7. Structure of alloy after holding at $1150{ }^{\circ} \mathrm{C}: a-$ transformation of eutectic carbide $\mathrm{M}_{7} \mathrm{C}_{3}$ to $\mathrm{M}_{23} \mathrm{C}_{6}$ and formation of the intermediate carbide $(\mathrm{FeCrNi})_{\mathrm{m}} \mathrm{C}_{\mathrm{n}}$ in the matrix $(\tau=2 \mathrm{~h}) ; b-$ formation of intermetallic phases $\sigma\left(\mathrm{FeCr}, \mathrm{Cr}_{5} \mathrm{NiFe}\right)$ and $\gamma^{\prime}\left(\mathrm{Fe}_{7} \mathrm{Cr}_{4} \mathrm{Ni}_{8} \mathrm{Si}_{2} \mathrm{Cr}_{7} \mathrm{Ni}_{5} \mathrm{Si}_{3} \mathrm{~N}_{3} \mathrm{FeNb}\right)(\tau=100 \mathrm{~h})$ 


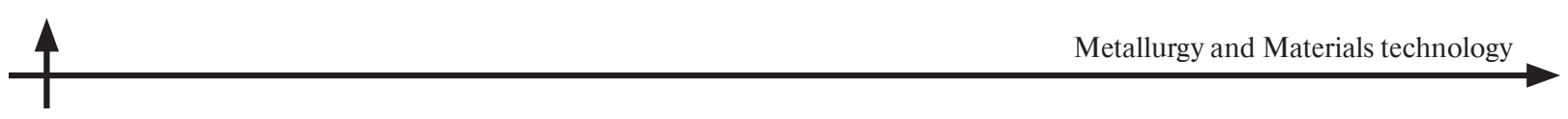

a)

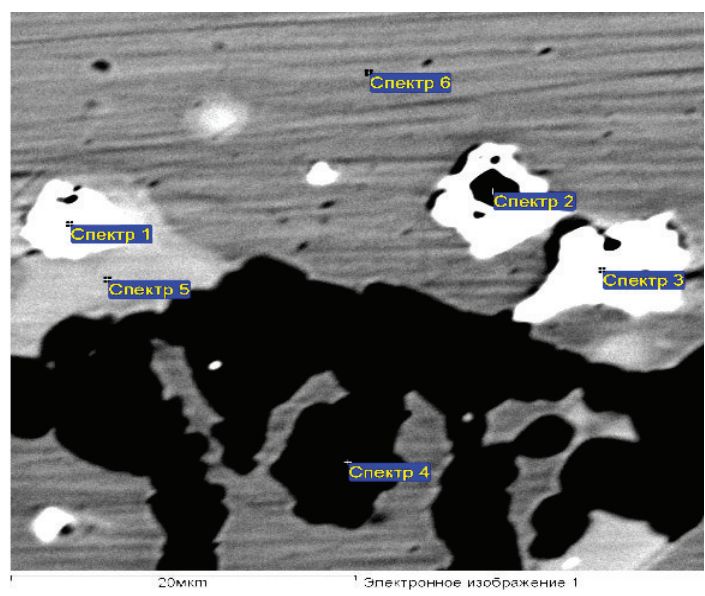

b)

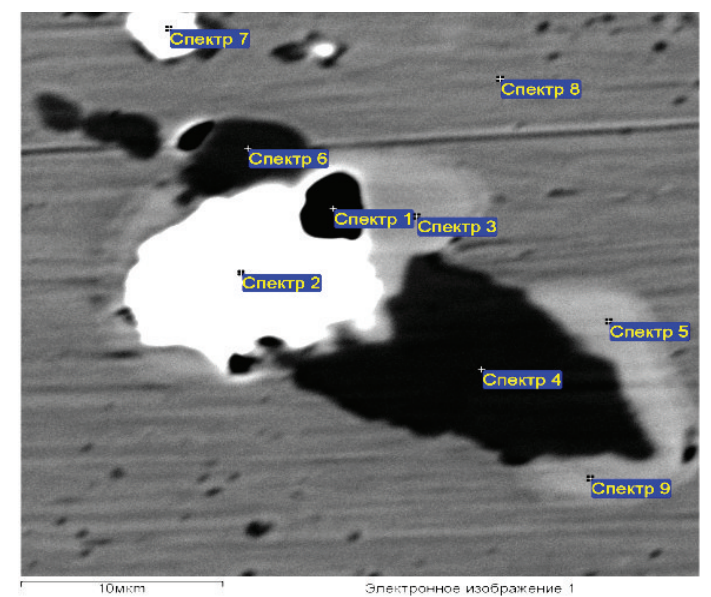

Fig. 8. Structure of alloy after holding at $1150{ }^{\circ} \mathrm{C}$ for $100 \mathrm{~h}: a-$ merging of niobium carbide (spectrum 1) and chromium carbide (spectrum 4) through formation of intermediate $\gamma^{\prime}$-phase (spectrum 5), $b$ - merging of chromium carbide (spectrum 4,6 ) and niobium carbide (spectrum)

2) through formation of intermediate $\gamma$-phase (spectrum $3,5,9$ )

Thus, cast structure of alloys of system C-25Cr$35 \mathrm{Ni}-\mathrm{Si}-\mathrm{Nb}$ is thermodynamic nonequilibrium. Analysis of the results of research suggests that in this case the main factors that provide high performance of $\mathrm{Fe}-\mathrm{Cr}-\mathrm{Ni}$ based superalloys are:

relatively low level of static loadings from $5 \mathrm{MPa}$ for operating temperature of $1150^{\circ} \mathrm{C}$ up to $70 \mathrm{MPa}$ - for $800^{\circ} \mathrm{C}$;

presence in the original cast structure, along with the matrix solid solution $\gamma$, a large number (up to $20 \%$, vol.) of coarse eutectic: base carbide $\left(\mathrm{M}_{7} \mathrm{C}_{3}\right.$ or $\mathrm{M}_{23} \mathrm{C}_{6}$ ) and $\gamma$-phase;

the formation of dispersed inclusions of carbide $\mathrm{M}_{\mathrm{m}} \mathrm{C}_{\mathrm{n}}$ in matrix outside of $5 \mu \mathrm{m}$ zone from the boundaries of eutectic chromium carbides due to diffusion to carbide $\mathrm{M}_{\mathrm{m}} \mathrm{C}_{\mathrm{n}}$ of excess carbon, produced at the modification of the eutectic chromium carbide at the reaction $23 \mathrm{M}_{7} \mathrm{C}_{3} \rightarrow 7 \mathrm{M}_{23} \mathrm{C}_{6}+27 \mathrm{C}$. Containing of metal elements in the carbide $\mathrm{M}_{\mathrm{m}} \mathrm{C}_{\mathrm{n}}$ at the initial stage of holding (2 hours) is (\%,wt.): $30 \mathrm{Cr}, 40 \mathrm{Fe}$, $20 \mathrm{Ni}$. This is close to their concentration in the matrix. By increasing the holding time to 50 hours, composition of dispersed carbides $\mathrm{M}_{\mathrm{m}} \mathrm{C}_{\mathrm{n}}$ in the matrix approaches the composition of eutectic carbide (\%, wt.): 55-60 Cr, 13-20 Fe, 8-12 Ni, $5 \mathrm{Nb}, 3 \mathrm{~W}, 6-9 \mathrm{C}$; additional hardening of structure by inclusion of relatively stable niobium carbide $(\mathrm{NbC})$;

continuous transformation of the initial phases in the structure at prolonged high temperature holding: chromium carbides $\left(\mathrm{M}_{7} \mathrm{C}_{3}\right)$ change their crystal struc- ture and transform to other ones (with lower relation of C / M concentration), niobium carbides dissolve with separation of niobium in solid matrix solution and formation of intermetallic phases;

continuous release and dissolution of various intermediate intermetallic phases at a stable matrix in the alloy structure of complex chemical composition. The intermetallic phases are formed at the boundary of the matrix and carbide phases. They have a conditional formula (in accordance with the results of determining of the chemical composition by microprobe analysis): $\mathrm{FeCr}, \mathrm{Cr}_{5} \mathrm{NiFe}, \mathrm{Fe}_{7} \mathrm{Cr}_{4} \mathrm{Ni}_{8} \mathrm{Si}$, $\mathrm{Cr}_{7} \mathrm{Ni}_{5} \mathrm{Si}_{3} \mathrm{~N}_{3} \mathrm{FeNb}$.

Obviously, growth and dissolution of intermediate carbide and intermetallic phases are determined by diffusion processes. For growth of chromium based carbides, these processes are determined by the diffusion of chromium in the conditions of "drift" under the influence of a potential field around the center of the new phase. Diffusion of the carbon does not limit the process at $\mathrm{T}=1150^{\circ} \mathrm{C}$ due to the high diffusion coefficient $\mathrm{D}<10^{-8} \mathrm{~cm}^{2} / \mathrm{s}$ and the mean free path of atoms in 1 hour $l=(\mathrm{D} \tau)^{0,5}<60 \mu \mathrm{m}$. For growth and dissolution of intermetallic phases this process is limited by diffusion of silicon and niobium. This demonstrates the kinetics of the increase or decrease in particle size of particular phase in time, if the process of growth or dissolution of the particles has already begun for some reason.

Forecast of formation of various intermediate phases in alloys containing more than 10 active 
chemical elements without explicit base (solvent), whose role play iron, nickel and chromium with about $90 \%$ (wt.) of the composition, at high temperatures and prolonged holdings, is a difficult analysis problem. Studies in recent years [1-4, 6, 10-14] show that the phase composition of these alloys changes continuously during prolonged high temperature holding. Currently, there are results of determining the composition of the intermediate phases, formed in the structure of the alloys after holding for up to 160 thousand hours [2], and the number of possible phases reaches up to 20 kinds.

Research conducted in this study show that the application of external low stress at high temperature holding stimulates the formation of a new phases intermetallic or carbonitride - in the structure of alloy. Growth kinetics of phases changes at a longtime load holding. Thus, at the boundaries of intragranular dislocation cells chromium carbides can be released, as well as intermetallic phases and nitrides.

\section{Conclusions}

Conditions of use for parts made of refractory heat resistant alloys $\mathrm{C}-25 \mathrm{Cr}-35 \mathrm{Ni}-\mathrm{Si}-\mathrm{Nb}$-system at temperatures of $900-1000^{\circ} \mathrm{C}$ with a possible temporary overheating to $1100-1200{ }^{\circ} \mathrm{C}(0,80-0,85$ from the solidus temperature) are extreme, considering tem- perature, as well as structural instability. Structural instability in this case is the continuous formation, growth and dissolution of intermediate carbide and intermetallic phases of variable composition, which are not in thermodynamic equilibrium. Argued thermodynamic evaluation of existence of intermediate phases in alloys of this components system, comprising multicomponent base - iron-chromium-nickel and several active structure stabilizing elements, is currently difficult. This is due to obvious experimentally confirmed (high holding at $0,80-0,85$ from the solidus temperature longer than 100 thousand hours) absence of thermodynamic equilibrium, which corresponds the achievement of final structural state with a stable set of phases. Thus, an important task at the present stage of research of such alloys is the accumulation of statistically compatible experimental results of direct instrumental determination of the chemical composition of the intermediate phases, formed in their structure during high temperature $(0,70-0,85$ from the solidus temperature) long (200 thousand hours or more) holding under operating stress. The results of these studies may help to determine the mechanisms of processes leading to the continuous changes in the structure of these alloys and to assess the likelihood of achieving of final structural state in them.

\section{REFERENCES}

1. Kenik E.A, Maziasz P.J, Swindeman R.W, Cervenka J, May $\mathbf{D}$. Structure and phase stability in cast modified-HP austenite after long-term ageing. Scripta Materialia. 2003. Vol. 49. P. 117-122.

2. Rudskoy A.I., Oryshchenko A.S., Kondrat'ev S.Yu., Anastasiadi G.P., Fuks M.D., Petrov S.N. Special Features of Structure and Long-Term Strength of Cast Refractory Alloy 45Kh26N33S2B2. Metal Science and Heat Treatment. 2013. Vol. 55. № 3-4. P. 209-215.

3. Ilman M.N. Kusmono Analysis of material degradation and life assessment of $25 \mathrm{Cr}-38 \mathrm{Ni}$-Mo-Ti wrought alloy steel (HPM) for cracking tubes in an ethylene plant. Eng Fail Anal. 2014. T. 42. № 100-8.

4. Rudskoy A.I., Kondrat'ev S.Yu., Anastasiadi G.P., Oryshchenko A.S., Fuks M.D., Petrov S.N. Transformation of the Structure of Refractory Alloy $0.45 \mathrm{C}-26 \mathrm{Cr}$ $33 \mathrm{Ni}-2 \mathrm{Si}-2 \mathrm{Nb}$ During a Long-Term High-Temperature Hold. Metal Science and Heat Treatment. 2014. Vol. 55. № 9-10. P. 517-525.

5. Rudskoy A.I., Oryshchenko A.S., Kondrat'ev S.Yu., Anastasiadi G.P., Fuks M.D. Mechanisms and Kinetics of Phase Transformations in Refractory Alloy 45Kh26N33S2B2 in Long-Term High-Temperature Holds. Part 1. Metal Science and Heat Treatment. 2014. Vol. 56. № 1-2. P. 3-8.
6. Rudskoy A.I., Kondrat'ev S.Yu., Anastasiadi G.P., Oryshchenko A.S., Fuks M.D. Mechanism and Kinetics of Phase Transformations in Refractory Alloy 45Kh26N33S2B2 Under Long-Term High-Temperature Holds. Part 2. Metal Science and Heat Treatment. 2014. Vol. 56. № 3-4. P. 124-130.

7. Sourmail T. Precipitates in creep resistant austenitic stainless steels. Mater Sci Technol. 2001;17/1:1-14.

8. Garbiak M, Chyliňska R. Precipitation kinetics in austenitic $18 \mathrm{Cr}-30 \mathrm{Ni}-\mathrm{Nb}$ cast steel. Arch Foundry Eng. 2008;8/3:27-30.

9. Rudskoi A.I., Anastasiadi G.P., Kondrat'ev S.Yu., Oryshchenko A.S., Fuks M.D. Effect of Electron Factor (Number of Electron Holes) on Kinetics of Nucleation, Growth, and Dissolution of Phases during Long-Term High-Temperature Holdings of $0.45 \mathrm{C}-26 \mathrm{Cr}-33 \mathrm{Ni}-2 \mathrm{Si}-$ 2Nb Superalloy. The Physics of Metals and Metallography. 2014. Vol. 115. № 1. P. 1-11.

10. Sustaita-Torres IA, Haro-Rodrigues S, GuerreroMata MP, De la Garza M, Valdes E, Deschaux-Beaume F, Colas R. Aging of cast $35 \mathrm{Cr}-45 \mathrm{Ni}$ heat resistant alloy. Materials Chemistry Physics. 2012. Vol. 133. P. 1018-1023.

11. Kondrat'ev S.Yu., Kraposhin V.S., Anastasiadi G.P., Talis A.L. Experimental observation and crystallographic 
description of $\mathrm{M} 7 \mathrm{C} 3$ carbide transformation in $\mathrm{Fe}-\mathrm{Cr}-$ Ni-C HP type alloy. Acta Materialia. 2015. Vol. 100. P. 275-281.

12. Monobe L.S., Schőn C.G. Microstructural and fractographic investigation of a centrifugally cast $20 \mathrm{Cr} 32 \mathrm{Ni}+\mathrm{Nb}$ alloy tube in the as cast and aged states. $J$ Mater Res Technol. 2013;2/2:195-201.

13. Borjali S, Allahkaram S.R, Khosravi H. Effects of working temperature and carbon diffusion on the microstructure of high pressure heat-resistant stainless steel tubes used in pyrolysis furnaces during service condition. Mater Des. 2012;34:65-73.

14. Nunes F.C, De Almeida L.H, Dille J, Deldlancke J-L, Le May I. Microstructural changes caused by yttri- um addition to NbTi-modified centrifugally cast HP-type stainless steels. Mater Char. 2007;58:132-42.

15. De Almeida L.H, Ribeiro A.F, Le May I.Microstructural characterization of modified $25 \mathrm{Cr}$ $35 \mathrm{Ni}$ centrifugally cast steel furnace tubes. Mater Char. 2003;49/3:219-29.

16. Buchanan K.G, Kral M.V. Crystallography and Morphology of Niobium Carbide in As-Cast HP-Niobium Reformer Tubes. Metall Mater Trans A. 2012;43A/6:1760-69.

17. Vander Voort G.F, Lucas G.M, Manilova E.P. Metallography and Microstructures of Heat-Resistant Alloys. In: Davis J.R., Davis \& Associates, editors. ASM International ASM Handbook, 2004, Vol. 9: Metallography and Microstructures. P. 820-59.

\section{СПИСОК ЛИТЕРАТУРЫ}

1. Kenik E.A, Maziasz P.J, Swindeman R.W, Cervenka J, May $\mathbf{D}$. Structure and phase stability in cast modified-HP austenite after long-term ageing. // Scripta Materialia. 2003. Vol. 49. P. 117-122.

2. Rudskoy A.I., Oryshchenko A.S., Kondrat'ev S.Yu., Anastasiadi G.P., Fuks M.D., Petrov S.N. Special Features of Structure and Long-Term Strength of Cast Refractory Alloy 45Kh26N33S2B2 // Metal Science and Heat Treatment. 2013. Vol. 55. № 3-4. P. 209-215.

3. Ilman M.N. Kusmono Analysis of material degradation and life assessment of $25 \mathrm{Cr}-38 \mathrm{Ni}-\mathrm{Mo}$-Ti wrought alloy steel (HPM) for cracking tubes in an ethylene plant // Eng Fail Anal. 2014. 42:100-8.

4. Rudskoy A.I., Kondrat'ev S.Yu., Anastasiadi G.P., Oryshchenko A.S., Fuks M.D., Petrov S.N. Transformation of the Structure of Refractory Alloy $0.45 \mathrm{C}-26 \mathrm{Cr}-$ 33Ni-2Si-2Nb During a Long-Term High-Temperature Hold // Metal Science and Heat Treatment. 2014. Vol. 55. № 9-10. P. 517-525.

5. Rudskoy A.I., Oryshchenko A.S., Kondrat'ev S.Yu., Anastasiadi G.P., Fuks M.D. Mechanisms and Kinetics of Phase Transformations in Refractory Alloy 45Kh26N33S2B2 in Long-Term High-Temperature Holds. Part $1 / /$ Metal Science and Heat Treatment. 2014. Vol. 56. № 1-2. P. 3-8.

6. Rudskoy A.I., Kondrat'ev S.Yu., Anastasiadi G.P., Oryshchenko A.S., Fuks M.D. Mechanism and Kinetics of Phase Transformations in Refractory Alloy 45Kh26N33S2B2 Under Long-Term High-Temperature Holds. Part 2 // Metal Science and Heat Treatment. 2014. Vol. 56. № 3-4. P. 124-130.

7. Sourmail T. Precipitates in creep resistant austenitic stainless steels // Mater Sci Technol. 2001. 17/1:1-14.

8. Garbiak M, Chyliňska R. Precipitation kinetics in austenitic $18 \mathrm{Cr}-30 \mathrm{Ni}-\mathrm{Nb}$ cast steel // Arch Foundry Eng. 2008. 8/3:27-30.

9. Rudskoi A.I., Anastasiadi G.P., Kondrat'ev S.Yu., Oryshchenko A.S., Fuks M.D. Effect of Electron Factor (Number of Electron Holes) on Kinetics of Nucleation,
Growth, and Dissolution of Phases during Long-Term High-Temperature Holdings of $0.45 \mathrm{C}-26 \mathrm{Cr}-33 \mathrm{Ni}-2 \mathrm{Si}-$ 2Nb Superalloy // The Physics of Metals and Metallography. 2014. Vol. 115. № 1. P. 1-11.

10. Sustaita-Torres I.A, Haro-Rodrigues S., Guerrero-Mata M.P., De la Garza M., Valdes E., DeschauxBeaume F., Colas R. Aging of cast $35 \mathrm{Cr}-45 \mathrm{Ni}$ heat resistant alloy // Materials Chemistry Physics. 2012. Vol. 133. P. 1018-1023.

11. Kondrat'ev S.Yu., Kraposhin V.S., Anastasiadi G.P., Talis A.L. Experimental observation and crystallographic description of $\mathrm{M} 7 \mathrm{C} 3$ carbide transformation in $\mathrm{Fe}-\mathrm{Cr}-$ Ni-C HP type alloy // Acta Materialia. 2015. Vol. 100. P. 275-281.

12. Monobe L.S., Schőn CG. Microstructural and fractographic investigation of a centrifugally cast $20 \mathrm{Cr} 32 \mathrm{Ni}+\mathrm{Nb}$ alloy tube in the as caśt and aged states // J. Mater Res Technol. 2013. 2/2:195-201.

13. Borjali S, Allahkaram SR, Khosravi H. Effects of working temperature and carbon diffusion on the microstructure of high pressure heat-resistant stainless steel tubes used in pyrolysis furnaces during service condition // Mater Des. 2012. 34:65-73.

14. Nunes F.C, De Almeida L.H, Dille J., Deldlancke J-L., Le May I. Microstructural changes caused by yttrium addition to NbTi-modified centrifugally cast HP-type stainless steels // Mater Char. 2007. 58:132-42.

15. De Almeida L.H., Ribeiro A.F., Le May I. Microstructural characterization of modified $25 \mathrm{Cr}-35 \mathrm{Ni}$ centrifugally cast steel furnace tubes // Mater Char. 2003. 49/3:219-29.

16. Buchanan K.G, Kral M.V. Crystallography and Morphology of Niobium Carbide in As-Cast HP-Niobium Reformer Tubes // Metall Mater Trans A. 2012. 43A/6:1760-69.

17. Vander Voort G.F, Lucas G.M, Manilova E.P. Metallography and Microstructures of Heat-Resistant Alloys. In: Davis J.R., Davis \& Associates, editors. ASM International ASM Handbook, 2004, Vol. 9: Metallography and Microstructures. P. 820-59. 


\section{СВЕДЕНИЯ ОБ АВТОРАX/AUTHORS}

KONDRAT EV Sergei Yu. - Peter the Great St. Petersburg Polytechnic University.

29 Politechnicheskaya St., St. Petersburg, 195251, Russia.

E-mail: petroprom2013@yandex.ru

КОНДРАТЬЕВ Сергей Юрьевич - доктор технических наук профессор Санкт-Петербургского политехнического университета Петра Великого.

195251, Россия, г. Санкт-Петербург, Политехническая ул., 29.

E-mail: petroprom2013@yandex.ru

ANASTASIADI Grigorii P. - Peter the Great St. Petersburg Polytechnic University.

29 Politechnicheskaya St., St. Petersburg, 195251, Russia.

E-mail: anastas45@yandex.ru

АНАСТАСИАДИ Григорий Панеодович - доктор технических наук профессор Санкт-Петербургского политехнического университета Петра Великого.

195251, Россия, г. Санкт-Петербург, Политехническая ул., 29.

E-mail: anastas45@yandex.ru

PTASHNIK Alina V. - Central Research Institute of Structural Materials "Prometey".

49, Shpalernaya str., St. Petersburg, 191015.

E-mail: alina_pv@mail.ru

ПТАШНИК Алина Вадимовна - инженер ЦНИИ «КМ «Прометей».

191015, Санкт-Петербург, Шпалерная ул., 49.

E-mail: alina_pv@mail.ru 